\section{Senegalese Experience of Kera- toplasties in Public and Private Practice (Aristide Le Dantec Hospital and Clinique du Cap), Dakar}

\section{Ndiaye JMM*, Roth E, Ndoye Roth PA, Wane AM, Ketoglo H, Sow AS, Kane H, Nguer M, Saheli Y and Ba EA}

Department of Ophthalmology, Hospital Aristide Le Dantec and Clinique du Cap, Dakar, Senegal

\begin{abstract}
Introduction: The corneal surface is exposed to many external aggressions which can alter its transparency and regularity. Several keratoplasty techniques have been codified such as Transfixing Keratoplasty (KT) or Deep Anterior Lamellar Keratoplasty (KLAP) or rotational auto graft. Our work was carried out in Senegal, in a context where corneal transplants were not frequently performed. The aim of our study was to report results one year after a keratoplasty.

Patients and Methods: We conducted a retrospective study of patients who underwent prior transfixing or lamellar keratoplasty or rotational auto graft. It was carried out between the ophthalmological clinic Aristide Le Dantec hospital and the ophthalmological center of Clinique du Cap in Dakar, Senegal. It included all records of patients with postoperative follow-up greater than or equal to 1 year. The parameters studied were anamnestic data, preoperative clinical examination (indication of corneal transplantation) and postoperative results.

Results: Twenty-six eyes of 22 patients were identified. The decrease in visual acuity evolved on average for 5 years. The operative indications were mainly represented by results of pillow type keratitis $(30.76 \%)$, bullous keratopathy $(23.08 \%)$, and keratoconus $(23.08 \%)$. Surgery consisted of a transfixing keratoplasty in $84.61 \%$, lamellar in $15.39 \%$ of the cases.
\end{abstract}

* ${ }^{*}$ orresponding author: Ndiaye JMM, Department of Ophthalmology, Hospital Aristide Le Dantec and Clinique du Cap, Dakar, Senegal, E-mail: josephmmndiaye@gmail.com

Citation: Ndiaye JMM, Roth E, Ndoye Roth PA, Wane AM, Ketoglo H, et al (2019) Senegalese Experience of Keratoplasties in Public and Private Practice (Aristide Le Dantec Hospital and Clinique du Cap), Dakar. J Ophthalmic Clin Res 6: 062.

Received: November 25, 2019; Accepted: December 17, 2019; Published: December 24, 2019

Copyright: @ 2019 Ndiaye JMM, et al. This is an open-access article distributed under the terms of the Creative Commons Attribution License, which permits unrestricted use, distribution, and reproduction in any medium, provided the original author and source are credited.
Comments: The primary objective of keratoplasty is to restore the transparency, it can also help to remedy pain or improve the anatomical and aesthetic prognosis of the eyeball. The benefits of keratoplasty in our context of developing countries are the reduced cost and shorter waiting time vis-à-vis western countries.

Conclusion: The results of our study are encouraging for surgery, still practiced on a small scale in our regions.

Keywords: Deep anterior lamellar keratoplasty; Eyeball; Surgery; Transfixing keratoplasty

\section{Introduction}

The corneal surface is exposed to many external aggressions which can alter its transparency and regularity, therefore causing its opacification or perforation. In this context corneal grafting, or keratoplasty, is necessary for the restoration of vision. According to the indications, several keratoplasty techniques have been codified such as Transfixing Keratoplasty (KT) or Deep Anterior Lamellar Keratoplasty (KLAP) or rotational auto graft. The KT consists of replacing a corneal disc in its entire thickness and KLAP consists of grafting the donor's epithelium and stroma to the recipient's membrane and endothelium. Our work was carried out in Senegal, in a context where corneal transplants were not frequently performed. The aim of our study was to report results one year after a keratoplasty.

\section{Patients and Methods}

We conducted a retrospective study of patients who underwent prior transfixing or lamellar keratoplasty or rotational auto graft. It was carried out between the ophthalmological clinic of Aristide Le Dantec hospital and the ophthalmological center of Clinique du Cap in Dakar, Senegal.

It included all records of patients with postoperative follow-up greater than or equal to 12 months. The parameters studied were anamnestic data, preoperative clinical examination (indication of corneal transplantation) and postoperative results.

For the KT, they were fresh grafts from the New York Eye Bank and San Diego Eye Bank (USA), delivered according to endothelial quality and regulatory health standards. Dry grafts for KLAP were from Keratec Eye Bank (Great Britain). The KLAP was made using the "big bubble" technique which consisted of a non-transfixing trepanation of $3 / 4$ of the cornea of the recipient, dissection of the stoma by injection of air and then of viscoelastic substance to maintain the endothelio-decematic layer [1]. The KT was performed according to the standard technique by trepanation.

Postoperative treatment included antibiotic corticosteroid (dexamethasone and tobramycin) and general antibiotic therapy. And Corticosteroid therapy could be increased depending on the condition of the graft. Surveillance was performed daily during hospitalization until the graft was re-epithelialized and surgical procedures were performed by the same surgeon. 
The best corrected visual acuity was measured on D1, D7, 1 month, 3 months, 6 months and 12 months. The expression of the final visual acuity in decimal value was made according to the formula [Decimal visual acuity $=10-\log M a r]$ with $\log M a r=-\log$ (visual acuity)

\section{Results}

Twenty-six eyes of 22 patients were identified. The average age of the patients was 39.2 years with extremes of 16 and 73 years and there was a male predominance with a sex ratio of 2.5 . The decrease in visual acuity evolved on average for 5 years with extremes of 4 months and 24 years. The time for the graft was variable according to the origin and it varied between 12 days and 3 months.

Ten patients had loss of both eyes. Preoperative visual acuity was less than $1 / 10^{\text {th }}$ in $88.46 \%$ of cases. The operative indications were mainly represented by results of pillow type keratitis $(30.76 \%)$, bullous keratopathy $(23.08 \%)$, and keratoconus $(23.08 \%)$. The remaining of patients had corneal dystrophies and corneal degeneration by burning (Table 1).

\begin{tabular}{|l|c|c|}
\hline \multicolumn{1}{|c|}{ Indication } & Number (n) & Percentage (\%) \\
\hline keratitis & 8 & 30.76 \\
\hline Bullous keratopaty & 6 & 23.08 \\
\hline Keratoconus & 6 & 23.08 \\
\hline Degeneration by burning & 2 & 7.69 \\
\hline Corneal dystrophies & 2 & 7.69 \\
\hline Cornea guttata & 2 & 7.69 \\
\hline
\end{tabular}

Table 1: Indications of keratoplasties.

The surgery was carried out under general anesthesia in $61.54 \%$ of the cases, it consisted of a transfixing keratoplasty in $84.61 \%$, lamellar in $15.39 \%$ of the cases.In the transfixing keratoplasty group, graft size was $8 \mathrm{~mm}$ in 7 cases $(31.82 \%)$ and $8.25 \mathrm{~mm}$ in 15 cases $(68.18 \%)$. For KLAP, the graft had a diameter of $8 \mathrm{~mm}$ in all cases. The graft was oversized $0.25 \mathrm{~mm}$ or $0.5 \mathrm{~mm}$ from the trepanning diameter of the receiving cornea.

Other interventions were performed at the same operative stage as transfixing Keratoplasty in $39.3 \%$ of cases. Ninety-one percent $(91 \%)$ of these combined surgeries involved intracapsular extraction and placement or repositioning of the implant. Regardless of the technique, no surgical complication was noted.

The re-epithelialization time was, on average, $6.33 \pm 2.80$ days for KT and 10 days for KLAP.

For evaluation of visual functional recovery, we removed the three cases of graft rejection, which had visual acuity at PL + . At one year postoperative, $37.5 \%$ operated eyes of KT and $100 \%$ of eyes operated on KAPL had better corrected visual acuity greater than or equal to $5 / 10^{\text {th }}$ (Figure 1). At 12 months, average decimal visual acuity was 0 , 2 for KT and 0, 6 KLAP (Figure 2).

Late postoperative complications were ocular hypertonia (21.4\%), graft rejection (21.4\%), superficial punctate keratitis (28.5\%), epithelialization delay $(7.14 \%)$, or a recurrence of the initial pathology on the graft. Visual acuity at 1 year postoperative was greater than or equal to 4 / 10 th in $46.42 \%$ of cases, and in $21 \%$ of cases it was greater than $9 / 10$.

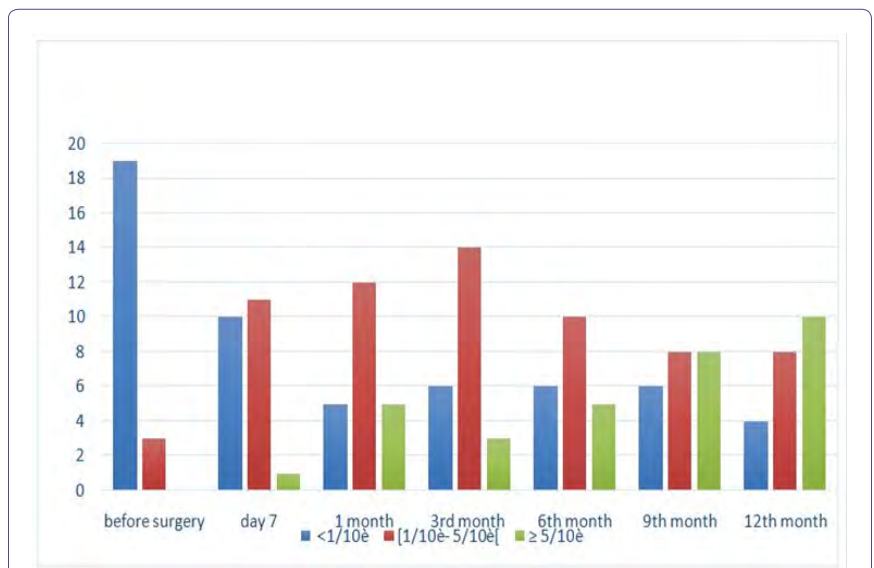

Figure 1: Evolution of visual acuity before and after keratoplasty.

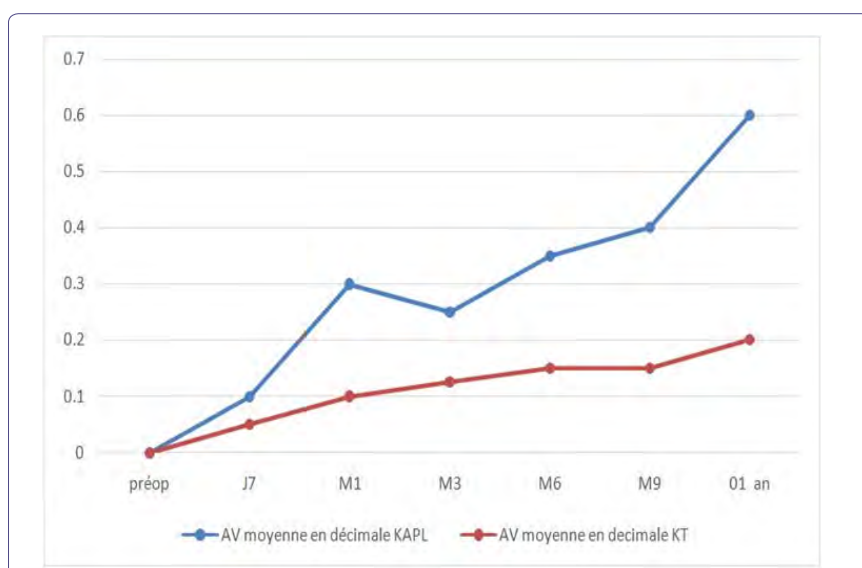

Figure 2: Evolution of visual acuity between KT and KAPL.

\section{Comments}

The primary objective of keratoplasty is to restore the transparency, shape and physiology of the cornea in order to restore useful vision for the patient. It can also help to remedy pain or improve the anatomical and aesthetic prognosis of the eyeball. The indications in patients in our cohort were dominated by results of infectious keratitis, whereas keratoconus predominated in several studies conducted in Caucasian populations [2-6]. Several complications can compromise the viability of the graft and worsen the visual prognosis.

In immediate surgery, rapid corneal reepithelialization is crucial to the survival of the graft [7]. The re-epithelialization delays are related to the topical postoperative treatment and especially the palpebral and lacrimal abnormalities of the recipient. It is necessary to evaluate the condition of the corneal epithelium. Ocular hypertension would be a factor of graft failure. It leads to loss of endothelial cells responsible for a loss of graft transparency [8]. Bullous keratopathy, a history of glaucoma and trauma are risk factors for increased postoperative intraocular pressure. Infectious keratitis after keratoplasty causes severe and often irreversible damage. Its impact would be higher in developing countries [9]. Although KLAP eliminates the risk of 
endothelial rejection, other rejections are possible such under epithelial and stromal. They must be treated in order to avoid failure of the lamellar graft.

Graft rejection remains the leading cause of keratoplasty in the immediate and late postoperative period [10]. This risk is increased in the case of corneal vasculature, the young age of the patient and incomprehension of the severity of the rejection by the patient $[11,12]$.

Functional recovery is difficult to predict after keratoplasty. Astigmatism is a factor limiting visual recovery when the graft is clear and in the absence of macular disease.

The benefits of keratoplasty in our context of developing countries are the reduced cost and shorter waiting time vis-à-vis western countries. However, there is the problem of follow-up because several patients are lost to follow-up after the first year of supervision.

\section{Conclusion}

The results of our study are encouraging for surgery, still practiced on a small scale in our regions. Faced with the increasing demand, it would be beneficial to create an "eye bank" for a better access to the graft and a reduction of treatment costs.

\section{References}

1. Borderie V, Bourcier T, Laroche L (2008) Les kératoplasties lamellaires à visée optique. Encycl Méd Chir, Ophtalmologie 21-020-C-10, p10.

2. Arne JL (2008) Les kératoplasties lamellaires antérieures. J Fr Ophtalmol 31: $902-906$.
3. Edwards M, Clover GM, Brookes N, Pendergrast D, Chaulk J, et al. (2002) Indications for corneal transplantation in New Zealand: 1991-1999. Cornea 21: 152-155.

4. Fasolo A, Frigo AC, Böhm E, Genisi C, Rama P, et al. (2006) The cortes study: corneal transplant indications and graft survival in an Italian cohort of patients. Cornea 25: 507-515.

5. Kanavi MR, Javadi MA, Sanagoo M (2007) Indications for penetrating keratoplasty in Iran. Cornea 26: 561-563.

6. Musa FU, Patil S, Rafiq O, Galloway P, Ball J, et al. (2012) Long-term risk of intraocular pressure elevation and glaucoma escalation after deep anterior lamellar keratoplasty. Clin Exp Ophthalmol 40: 780-785.

7. Chéour M, Nasri H, Kamoun H, Lamloum H, Kasri A, et al. (2008) Les facteurs intervenant dans la réépithélialisation cornéenne après kératoplastie transfixiante. J Fr Ophtalmol 31: 786-789.

8. Allouch C, Borderie V, Touzeau O, Scheer S, Nordmann JP, et al. (2003) Incidence et facteurs de risque de l'hypertonie oculaire au cours des kératoplasties transfixiantes. J Ophthalmol 26: 553-561.

9. Vajpayee RB, Sharma N, Sinha R, Agarwal T, Singhvi A (2007) Infectious keratitis following keratoplasty. Surv Ophthalmol 52: 1-12.

10. Panda A, Vanathi M, Kumar A, Dash Y, Priya S (2007) Corneal graft rejection. Surv Ophthalmol 52: 375-396.

11. Sellami D, Abid S, Bouaouaja G, Ben Amor S, Kammoun B, et al. (2007) Epidemiology and risk factors for corneal graft rejection. Transplant Proc 39: 2609-2611.

12. Trigui A, Smaoui M, Masmoudi J, Mhiri W, Maatoug S, et al. (2005) Corneal graft rejection: donor and receiver implication. J Fr Ophtalmol 28: 631-634. 


\section{II \\ HERALD}

Journal of Anesthesia \& Clinical Care

Journal of Addiction \& Addictive Disorders

Advances in Microbiology Research

Advances in Industrial Biotechnology

Journal of Agronomy \& Agricultural Science

Journal of AIDS Clinical Research \& STDs

Journal of Alcoholism, Drug Abuse \& Substance Dependence

Journal of Allergy Disorders \& Therapy

Journal of Alternative, Complementary \& Integrative Medicine

Journal of Alzheimer's \& Neurodegenerative Diseases

Journal of Angiology \& Vascular Surgery

Journal of Animal Research \& Veterinary Science

Archives of Zoological Studies

Archives of Urology

Journal of Atmospheric \& Earth-Sciences

Journal of Aquaculture \& Fisheries

Journal of Biotech Research \& Biochemistry

Journal of Brain \& Neuroscience Research

Journal of Cancer Biology \& Treatment

Journal of Cardiology: Study \& Research

Journal of Cell Biology \& Cell Metabolism

Journal of Clinical Dermatology \& Therapy

Journal of Clinical Immunology \& Immunotherapy

Journal of Clinical Studies \& Medical Case Reports

Journal of Community Medicine \& Public Health Care

Current Trends: Medical \& Biological Engineering

Journal of Cytology \& Tissue Biology

Journal of Dentistry: Oral Health \& Cosmesis

Journal of Diabetes \& Metabolic Disorders

Journal of Dairy Research \& Technology

Journal of Emergency Medicine Trauma \& Surgical Care

Journal of Environmental Science: Current Research

Journal of Food Science \& Nutrition

Journal of Forensic, Legal \& Investigative Sciences

Journal of Gastroenterology \& Hepatology Research

Journal of Gerontology \& Geriatric Medicine

Journal of Genetics \& Genomic Sciences

Journal of Hematology, Blood Transfusion \& Disorders

Journal of Human Endocrinology

Journal of Hospice \& Palliative Medical Care

Journal of Internal Medicine \& Primary Healthcare

Journal of Infectious \& Non Infectious Diseases

Journal of Light \& Laser: Current Trends

Journal of Modern Chemical Sciences

Journal of Medicine: Study \& Research

Journal of Nanotechnology: Nanomedicine \& Nanobiotechnology

Journal of Neonatology \& Clinical Pediatrics

Journal of Nephrology \& Renal Therapy

Journal of Non Invasive Vascular Investigation

Journal of Nuclear Medicine, Radiology \& Radiation Therapy

Journal of Obesity \& Weight Loss

Journal of Orthopedic Research \& Physiotherapy

Journal of Otolaryngology, Head \& Neck Surgery

Journal of Protein Research \& Bioinformatics

Journal of Pathology Clinical \& Medical Research

Journal of Pharmacology, Pharmaceutics \& Pharmacovigilance

Journal of Physical Medicine, Rehabilitation \& Disabilities

Journal of Plant Science: Current Research

Journal of Psychiatry, Depression \& Anxiety

Journal of Pulmonary Medicine \& Respiratory Research

Journal of Practical \& Professional Nursing

Journal of Reproductive Medicine, Gynaecology \& Obstetrics

Journal of Stem Cells Research, Development \& Therapy

Journal of Surgery: Current Trends \& Innovations

Journal of Toxicology: Current Research

Journal of Translational Science and Research

Trends in Anatomy \& Physiology

Journal of Vaccines Research \& Vaccination

Journal of Virology \& Antivirals

Archives of Surgery and Surgical Education

Sports Medicine and Injury Care Journal

International Journal of Case Reports and Therapeutic Studies

Submit Your Manuscript: http://www.heraldopenaccess.us/Online-Submission.php 